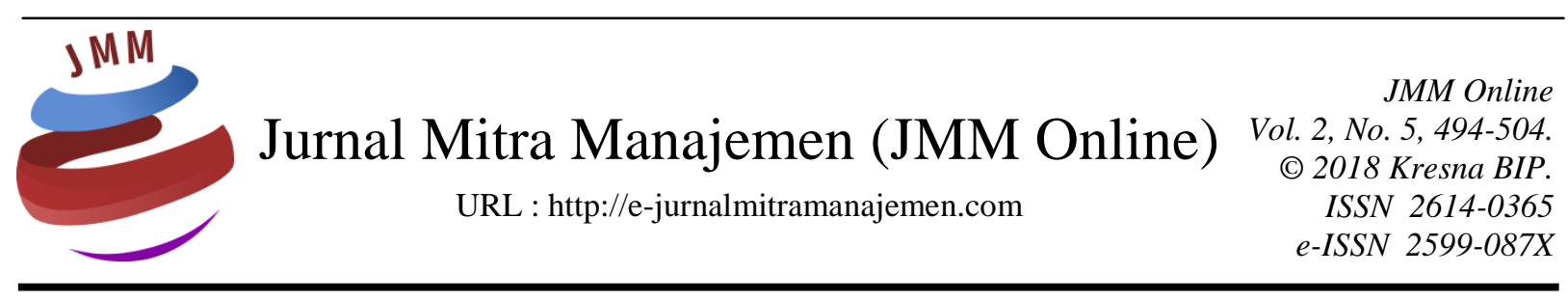

\title{
PENGARUH PENGETAHUAN MANAJEMEN TERHADAP KEPUASAN KERJA KARYAWAN
}

\author{
Afi Parnawi \\ STAI Ibnu Sina Batam
}

\section{INFORMASI ARTIKEL}

Dikirim : 06 September 2018

Revisi pertama : 09 September 2018

Diterima : 11 September 2018

Tersedia online : 28 September 2018

Kata Kunci : Pengaruh, Pengetahuan Manajemen, Kepuasan Kerja Karyawan

Email : affi354@gmail.com

\section{ABSTRAK}

Penelitian ini dilatar belakangi dari rasa puas dan ketidak puasan kerja karyawan pada suatu organisasi yang dipimpin oleh seorang kepala madrasah. Keberhasilan kepala madrasah dalam mengelola organisasinya tidak lepas dari pengetahuan manajemen, gaya kepemimpinan dan komunikasi interpersonalnya.

Penelitian ini adalah penelitian kuantitatif dengan metode survey. Hasil riset adalah bahwa pengetahuan manajemen berpengaruh positif dan signifikan terhadap kepuasan kerja karyawan baik secara parsial maupun secara simultan. Dari hasil analisis determinasi masih ada faktor lain yang mempengaruhi kepuasan kerja karyawan selain variabel pengetahuan manajemen. Semakin baik pengetahuan manajemen maka akan semakin baik pula kepuasan kerja karyawan pada Madrasah Aliyah Negeri Provinsi Kepulauan Riau. 


\section{PENDAHULUAN \\ Latar Belakang}

Kualitas manusia yang dibutuhkan oleh bangsa Indonesia pada masa kini dan masa depan adalah mampu menghadapi persaingan yang semakin ketat dengan bangsa lain di dunia. Kualitas manusia Indonesia tersebut dihasilkan melalui penyelenggaraan pendidikan yang bermutu oleh pendidik profesional dan tenaga kependidikan yang handal. Untuk mencapai fungsi dan tujuan pendidikan tersebut maka peran kepala sekolah dan tenaga kependidikan dalam mendidik peserta didik begitu berarti.

Menurut Undang-Undang No 20 Tahun 2003 tentang Sistem Pendidikan Nasional pasal 1 ayat 5 dan 6 yang dimaksud dengan tenaga kependidikan adalah anggota masyarakat yang mengabdikan diri dan diangkat untuk menunjang penyelenggaraan pendidikan. Oleh karena itu, karyawan merupakan stakeholder internal yang berharga serta membantu mengembangkan iklim kerjasama dan kepercayaan bersama. Karyawan sebagai tenaga profesional mempunyai visi terwujudnya penyelenggaraan pendidikan sesuai dengan prinsip-prinsip profesional untuk memenuhi hak yang sama bagi setiap warga Negara dalam memperoleh pendidikan yang bermutu.

Aqib dalam Suwar dan Muchlisin mengatakan (2008) bahwa karyawan adalah faktor penentu bagi keberhasilan pendidikan di madrasah karena karyawan merupakan sentral serta sumber kegiatan belajar mengajar. Hal ini menunjukkan bahwa kemampuan atau kompetensi profesional seorang karyawan sangat menentukan mutu pendidikan dan tidak dapat dipungkiri bahwa karyawan merupakan aset berharga organisasi pendidikan, yaitu madrasah/sekolah. Hal tersebut juga dikemukakan oleh Day, menurutnya (2012) karyawan adalah aset madrasah terbesar karena ia sebagai pengetahuan, keterampilan, dan nilai-nilai. Berdasarkan hadist Shahih Bukhari yang berbunyi sebagai berikut:

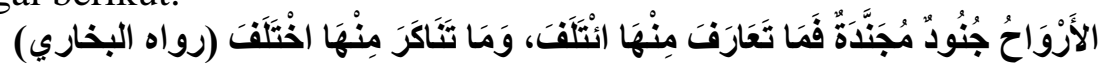

Artinya : Beberapa ruh itu saling bolo-membolo maka apa-apa yang saling mengenal darinya akan menyatu, dan apa-apa yang saling mengingkari darinya maka akan berselisih (H.R Bukhori).

Karyawan dituntut pula bekerja dengan memberikan pelayanan sebaiksebaiknya kepada pemakai madrasah seperti siswa, orangtua dan masyarakat. Hal tersebut sejalan dengan tujuan akhir yang ingin dicapai oleh manajemen sumber daya manusia yaitu tingginya kualitas pelayanan, dan rendahnya complain dari pemakai. Ella Jauyani Sagala (2009) mengungkapkan dalam rangka mencapai tujuan akhir tersebut secara bertahap perlu dicapai tujuan-tujuan perantara yaitu diperolehnya SDM yang memenuhi dengan keterampilan, keahlian, dan pengetahuan yang sesuai dengan perkembangan, SDM yang memenuhi syarat bersedia bekerja sebaik mungkin, SDM yang memenuhi syarat yang berdedikasi terhadap organisasi yang luas terhadap pekerjaannya.

Aspek-aspek pekerjaan yang bersentuhan langsung dengan individu maupun kelompok antara lain adalah bagaimana pengelolaan suatu lembaga atau instansi dalam memberikan kepuasan terhadap karyawan atau pegawainya. Menurut Husaini (2014) manajemen dalam arti luas adalah perencanaan, pelaksanaan dan pengawasan sumber daya organisasi untuk mencapai tujuan secara efektif dan efisien. Salah satu bidang 
yang tidak kalah penting dalam manajemen adalah perilaku organisasi. Perilaku organisasi berkaitan dengan bagaimana orang bertindak dan berinteraksi dalam organisasi. Beberapa teori perilaku organisasi memuat kepuasan kerja (job statisfaction) sebagai salah perilaku organisasi yang memberikan kontribusi terhadap tujuan organisasi dalam sistem manajemen. Sebagaimana diterangkan dalam QS Ali Imran Ayat 103 yang berbunyi:

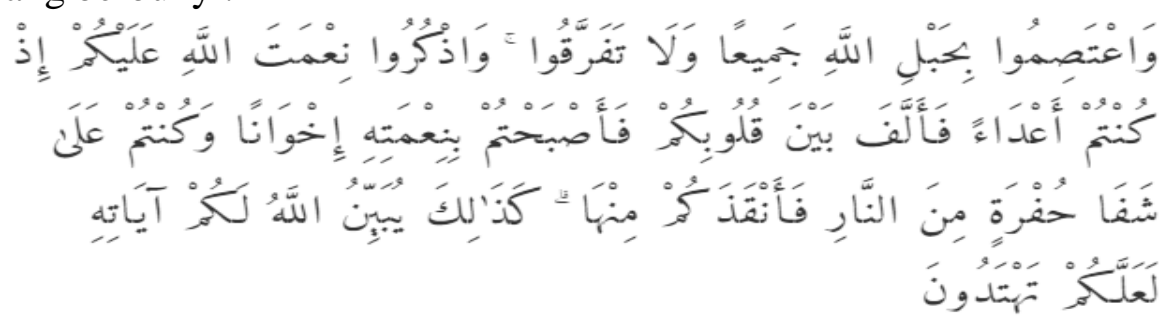

Artinya : Dan berpeganglah kamu semuanya kepada tali (agama) Allah, dan janganlah kamu bercerai berai, dan ingatlah akan nikmat Allah kepadamu ketika kamu dahulu (masa Jahiliyah) bermusuh-musuhan, Maka Allah mempersatukan hatimu, lalu menjadilah kamu karena nikmat Allah, orang-orang yang bersaudara; dan kamu telah berada di tepi jurang neraka, lalu Allah menyelamatkan kamu dari padanya. Demikianlah Allah menerangkan ayatayat-Nya kepadamu, agar kamu mendapat petunjuk.

Madrasah sebagai organisasi memiliki dua kelompok besar pengelola organisasi yaitu pengelolaan tenaga pendidik dan tenaga kependidikan. Menurut undang-undang nomor 20 tahun 2004 pasal 39 tentang Sistem Pendidikan Nasional, tenaga kependidikan bertugas melaksanakan administrasi, pengelolaan, pengembangan, pengawasan dan pelayanan teknis untuk menunjang proses pendidikan pasa satuan pendidikan. Kepuasan kerja tenaga kependidikan sudah sepatutnya mendapat perhatian yang serius, mengingat begitu besarnya tugas yang diemban seperti yang tertuang dalam Undang-Undang Sistem Pendidikan Nasional yang telah dikutip di atas. Sebagaimana Allah swt telah berfirman dalam QS Al-Alaq ayat 1- 6 yang berbunyi sebagai berikut:

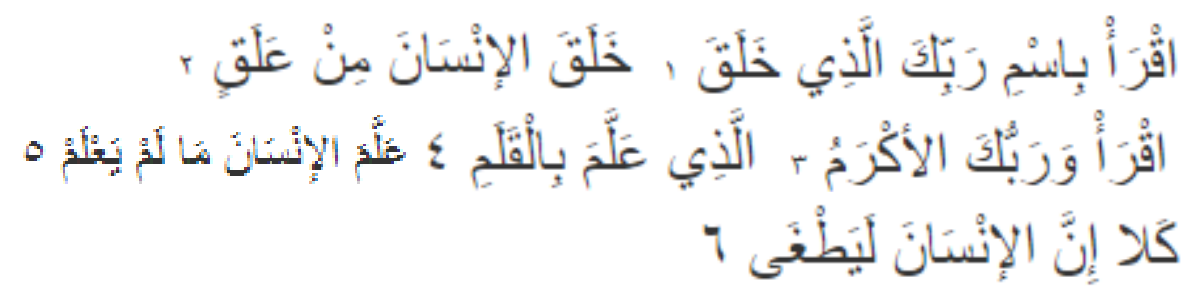

Artinya :1. Bacalah dengan (menyebut) nama Tuhanmu yang Menciptakan

2. Dia telah menciptakan manusia dari segumpal darah.

3. Bacalah, dan Tuhanmulah yang Maha pemurah,

4. Yang mengajar (manusia) dengan perantaran kalam

5. Dia mengajar kepada manusia apa yang tidak diketahuinya.

6. Ketahuilah, sesungguhnya manusia benar-benar melampaui Batas.

Dalam Al Hadits juga diterangkan bahwa setiap orang dituntut untuk bisa bertanggungjawab, termasuk bekerja, menduduki jabatan, mencari maisyah dll dituntut 
yang baik. Sebagaimana dalam sebuah hadits At-Tirmidzi yang berbunyi sebagai berikut:

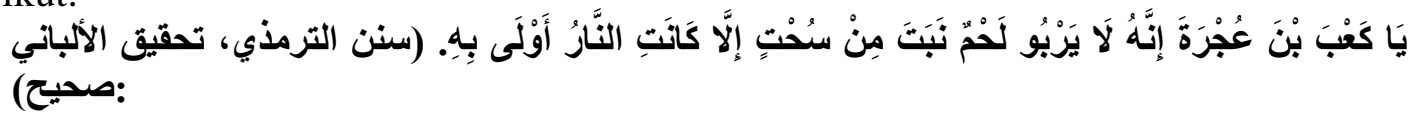

Artinya : Wahai Ka'ab bin Ujrah, sesungguhnya tidaklah tumbuh setiap daging yang diberi asupan makanan yang haram melainkan nerakalah yang berhak membakarnya.

Kepemimpinan dalam lembaga pendidikan merupakan salah satu variabel yang berpengaruh terhadap kepuasan kerja tenaga kependidikan seperti yang telah dipaparkan diatas. Kepemimpinan biasa dianalogikan dengan cara memimpin yang di perankan oleh seorang pemimpin, di lembaga pendidikan khususnya madrasah yang dimaksud dengan pemimpin adalah kepala madrasah. Kepemimpinan menurut Northouse (2013) memiliki empat komponen yaitu proses, pengaruh, melibatkan kelompok dan tujuan bersama, sehingga kepemimpinan didefenisikanya sebagai proses dimana individu mempengaruhi kelompok individu untuk mencapai tujuan bersama. Lebih lanjut dijelaskan oleh Northouse, kepemimpinan sebagai proses, diartikan bahwa kepemimpinan merupakan peristiwa yang interaktif ada peristiwa saling mempengaruhi antara pemimpin dan pengikut, elemen yang terpenting dalam kepemimpinan adalah pengaruh yang menggambarkan eksisitas seorang pemimpin, kelompok dipandang sebagai sasaran kepemimpinan seseorang, tanpa kelompok kepemimpinan tidak akan pernah ada, komponen yang mempersatukan pemimpimpin dan individu-individu atau kelompok diperkuat dengan tujuan bersama.

Perspektif tentang pemimpin yang efektif dapat dikaji dengan melihat dimensidimensi apa saja yang dapat menjadi kreteria tentang pemimpin yang efektif. Menurut Yukl, ukuran yang bisa digunakan mengenai efektivitas kepemimpinan adalah sejauh mana unit organisasi dari pemimpin tersebut melaksanakan tugasnya secara berhasil dan mencapai tujuan-tujuannya. Sikap para pengikut juga menjadi indikator umum lain dari efektivitas seorang pemimpin. Sikap tersebut meliputi pemuasan dari pemimpin terhadap kebutuhan-kebutuhan dan harapan-harapan pengikut, sejauh mana pengikut menyukai, menghormati, dan mengagumi pemimpin, adanya komitmen yang kuat dari pengikut untuk melaksanakan permintaan-permintaan dari pemimpin, atau para pengikut akan menentang, mengabaikan atau menumbangkannya.

Dampak ketidak puasan terhadap pekerjaan, menurut Robbins and Judge adalah (1) exsit, respon keluar mengarahkan perilaku ke arah meninggalkan organisasi, termasuk mencari posisi baru serta mengundurkan diri, (2) voice, respon suara termasuk aktif dan konstruktif mencoba untuk memperbaiki kondisi, termasuk mengusulkan perbaikan, mendiskusikan masalah dengan atasan, dan melakukan beberapa bentuk kegiatan serikat, (3) loyalty, tanggapan loyalitas berarti pasif tetapi optimis menunggu untuk kondisi membaik, termasuk berbicara untuk organisasi dalam menghadapi kritik eksternal dan mempercayai organisasi dan manajemen untuk melakukan hal yang benar dan (4) neglect, tanggapan mengabaikan pasif memungkinkan kondisi memburuk dan termasuk absensi kronis atau keterlambatan, mengurangi usaha, dan peningkatan tingkat kesalahan.

Berdasarkan pendapat yang telah dipaparkan diatas, kondisi eksternal yang berpengaruh terhadap kepuasan kerja salah satunya adalah kepemimpinan, dalam 
konteks lembaga pendidikan tingkat madrasah yang perpengaruh terhadap kepuasan kerja tenaga kependidikan adalah pemimpin. Kepemimpinan dalam lembaga pendidikan merupakan salah satu variabel yang berpengaruh terhadap kepuasan kerja tenaga kependidikan seperti tata usaha dan stafnya, pegawai perpustakaan beserta stafnya, tenaga laboratorium beserta stafnya, cleaning service serta sekuriti. Kepemimpinan biasa dianalogikan dengan cara memimpin yang diperankan oleh seorang pemimpin, di lembaga pendidikan khususnya madrasah yang dimaksud dengan pemimpin adalah kepala madrasah. Kepemimpinan menurut Northouse, memiliki empat komponen yaitu proses, pengaruh, melibatkan kelompok dan tujuan bersama, sehingga kepemimpinan didefinisikannya sebagai proses dimana individu mempengaruhi kelompok individu untuk mencapai tujuan bersama. Lebih lanjut dijelaskan oleh Northouse, kepemimpinan sebagai proses, diartikan bahwa kepemimpinan merupakan peristiwa yang interaktif ada peristiwa saling mempengaruhi antara pemimpin dan pengikut, elemen yang terpenting dalam kepemimpinan adalah pengaruh yang menggambarkan eksisitas seorang pemimpin, kelompok dipandang sebagai sasaran kepemimpinan seseorang, tanpa kelompok kepemimpinan tidak akan pernah ada, komponen yang mempersatukan pemimpimpin dan individu-individu atau kelompok diperkuat dengan tujuan bersama.

Perspektif tentang pemimpin yang efektif dapat dikaji dengan melihat dimensidimensi apa saja yang dapat menjadi kreteria tentang pemimpin yang efektif. Menurut Yukl (2015) ukuran yang bisa digunakan mengenai efektivitas kepemimpinan adalah sejauh mana unit organisasi dari pemimpin tersebut melaksakan tugasnya secara berhasil dan mencapai tujuan-tujuannya. Sikap para pengikut juga menjadi indikator umum lain dari efektivitas seorang pemimpin. Sikap tersebut meliputi pemuasan dari pemimpin terhadap kebutuhan-kebutuhan dan harapan-harapan pengikut, sejauh mana pengikut menyukai, menghormati, dan mengagumi pemimpin, adanya komitmen yang kuat dari pengikut untuk melaksanakan permintaan-permintaan dari pemimpin, atau para pengikut akan menentang, mengabaikan atau menumbangkannya. Allah telah berfirman dalam QS Al-Ankabut ayat 69 yang berbunyi :

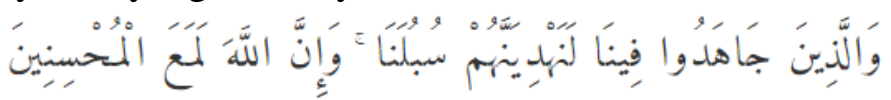

Artinya : Dan orang-orang yang berjihad untuk (mencari keridhaan) Kami, benarbenar akan Kami tunjukkan kepada mereka jalan-jalan kami, dan sesungguhnya Allah benar-benar beserta orang-orang yang berbuat baik.

Dan QS An-Nisa ayat 59 yang berbunyi sebagai berikut:

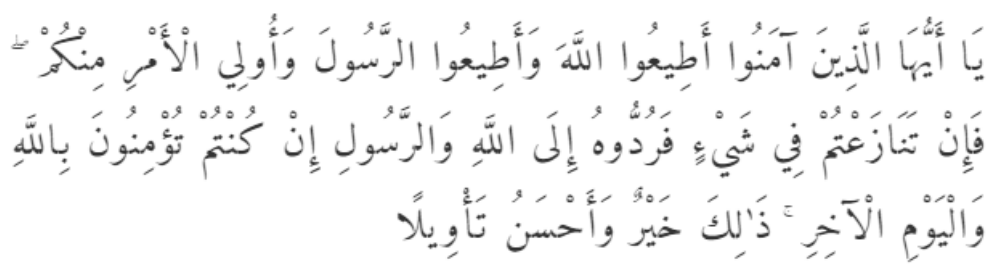

Artinya : Hai orang-orang yang beriman, taatilah Allah dan taatilah Rasul (Nya), dan ulil amri di antara kamu, kemudian jika kamu berlainan pendapat tentang sesuatu, maka kembalikanlah ia kepada Allah (Al Quran) dan Rasul 
(sunnahnya), jika kamu benar-benar beriman kepada Allah dan hari kemudian, yang demikian itu lebih utama (bagimu) dan lebih baik akibatnya.

\section{Pembahasan}

Penelitian tentang kepuasaan kerja karyawan di Madrasah Aliyah Kabupaten/Kota dalam kepemimpinan kepala Madrasah Aliyah kepada 30 (tiga puluh) karyawan di Kabupaten Bintan yang telah dilaksanakan dengan penyebaran kuesioner, wawancara, dan observasi. Data hasil penyebaran angket diperoleh sebagai berikut:

Tabel 1. Hasil Penyebaran Angket Variabel Kepuasan Kerja Karyawan di MAN Kota Bintan Tahun 2018

\begin{tabular}{|l|l|r|c|c|c|c|l|}
\hline \multirow{2}{*}{ No } & \multirow{2}{*}{ Indikator } & \multicolumn{5}{|c|}{ Penilaian } & \multirow{2}{*}{ Jumlah } \\
\cline { 3 - 7 } & & SP & P & CP & KP & STP & \\
\hline 1. & Pekerjaan itu sendiri & $10 \%$ & $45 \%$ & $15 \%$ & $15 \%$ & $15 \%$ & $100 \%$ \\
\hline 2. & Penghasilan & $10 \%$ & $45 \%$ & $20 \%$ & $15 \%$ & $10 \%$ & $100 \%$ \\
\hline 3. & Pengawasan & $10 \%$ & $15 \%$ & $15 \%$ & $45 \%$ & $15 \%$ & $100 \%$ \\
\hline 4. & Promosi & $10 \%$ & $10 \%$ & $20 \%$ & $45 \%$ & $15 \%$ & $100 \%$ \\
\hline 5. & Rekan Kerja & $10 \%$ & $20 \%$ & $15 \%$ & $40 \%$ & $15 \%$ & $100 \%$ \\
\hline
\end{tabular}

Sumber : Hasil Penelitian, diolah (2018)

Berdasarkan tabel 1 melalui penyebaran angket terlihat bahwa kepuasan kerja karyawan Madrasah Aliyah Negeri Kota Bintan dapat dilihat berdasarkan indikator kepuasan kerja karyawan sebagai berikut :1). Pekerjaan itu sendiri 45\% responden menyatakan puas, hal ini berarti baik 2). Penghasilan $45 \%$ menyatakan puas dan $10 \%$ menyatakan sangat puas, ini berarti baik, 3). Pengawasan $45 \%$ kurang puas, berarti kurang baik, 4). Promosi $45 \%$ yang menyatakan kurang puas, ini berarti kurang baik, 5). Rekan kerja $40 \%$ menyatakan kurang puas, ini berarti kurang baik, ini berarti baik dari 5 indikator yang ada, dapat dilihat 2 indikator yang masuk kategori puas yaitu pekerjaan itu sendiri dan penghasilan, meskipun demikian angka puas ini juga mendekati pada angka yang kurang puas sehingga perlu upaya yang lebih maksimal lagi untuk memberikan layanan yang baik kepada karyawan. Berdasarkan pada hasil pengisian kuesioner dan dihitung berdasakan pada pedoman penskoran, maka dapat dipahami bahwa kepuasan kerja karyawan madrasah Aliyah dalam kepemimpinan kepala madrasah termasuk kategori kurang baik.

Untuk melihat keterwakilan setiap wilayah maka penelitian ini dilakukan pada MAN yang memiliki nilai akreditasi A. Dilihat dari data awal yang didapat oleh peneliti yang telah dipaparkan di atas, maka penelitian dilakukan di wilayah Provinsi Kepulauan Riau Kabupaten Bintan .

\section{Kepuasan Kerja Karyawan}

Menurut Sondang Siagian (2009) kepuasan adalah cara pandang seseorang baik bersifat positif atau yang bersifat negatif tentang sesuatu. Secara sederhana kepuasan dapat diartikan sebagai tingkat perasaan seseorang setelah membandingkan kinerja produk (atau hasil) yang ia rasakan dengan harapannya.

Kepuasan kerja pada prinsipnya suatu hal yang bersifat individual. Hal mana setiap individu memiliki tingkat kepuasan yang berbeda sesuai dengan sistem nilai 
yang berlaku pada dirinya. Semakin banyak aspek-aspek dalam pekerjaan yang sesuai dengan individu tersebut tercapai, semakin tinggi tingkat kepuasan yang dirasakan.

Belum mengatakan bahwa kepuasaan kerja adalah sikap umum yang merupakan hasil dari sikap khusus terhadap skor-skor pekerjaan, penyesuaian diri dan hubungan sosial individu. Menurut Stephen P Robbins (2009) kepuasan adalah suatu perasaan positif seseorang (pelanggan) tentang pekerjaan seseorang yang merupakan hasil dari sebuah evaluasi karakteristiknya dan setelah membandingkan antara kinerja atau hasil yang dirasakan (pelayanan yang diterima dan dirasakan) dengan yang diharapkannya. Menurut Veithzal Rivai (2009) kepuasan adalah penilaian dari seseorang tentang seberapa jauh pekerjaannya secara keseluruhan memuaskan kebutuhannya atau sikap umum yang merupakan hasil dari beberapa sikap khusus terhadap faktor-faktor pekerjaaan, penyesuaian diri dan hubungan sosial individu di luar kerja.

Selanjutnya Handoko (2011) mengatakan bahwa batasan kepuasan kerja sebagai keadaan emosional yang menyenangkan dengan mana para karyawan memandang pekerjaan mereka. Kepuasaan kerja mencerminkan perasaan seseorang terhadap pekerjaannya. Ini dalam dampak sikap positif karyawan terhadap pekerjaan dan segala sesuatu yang dihadapi di lingkungan kerjanya.

Adapun indikator dari kepuasan kerja karyawan adalah sebagai berikut: (1) pekerjaan itu sendiri dengan tanggung jawab, minat dan pergembangan diri (2) Kompensasi dengan indikator pembayaran gaji yang tepat waktu (3) promosi dengan indikator dengan kesempatan promosi, dan jenjang karir.

\section{Pengetahuan Manajemen}

Secara bahasa (etimologi), pengetahuan berasal dari bahasa inggris yaitu knowledge. Dalam Encyclopedia Of Philosophy dijelaskan bahwa definisi pengetahuan adalah "kepercayaan yang benar (knowledgeis justified true belief). Menurut Jalaluddin (2013) pengetahuan adalah produk dari tahu, yakni mengerti sesudah melihat, menyaksikan dan mengalami.

Manajemen adalah usaha pencapaian tujuan-tujuan organisasi dengan cara yang efektif dan efisien melalui kegiatan planning, organizing, leading dan controlling sumber daya organisasi. Sedangkan The Liang Gie (1978) memberi batasan manajemen sebagai segenap perbuatan menggerakkan sekelompok orang/mengerahkan segala fasilitas dalam suatu usaha kerja sama untuk mencapai tujuan tertentu.

Inti kegiatan manajemen pendidikan persekolah adalah pembuatan keputusan untuk peningkatan mutu kinerja sekolah.Dilihat dari konsep inovasi, pembuatan keputusan sebagai inti manajemen pendidikan mengandung makna keputusan inovatif jika keputusan dibuat dan dianggap baru oleh pihak-pihak yang berkepentingan dengan keputusan itu. Mengikuti alur pengembangan inovasi (innovation-develop-ment process) dalam bidang manajemen pendidikan dapat dilakukan dengan menempuh proses (1) recognizing a problem or need, (2) research, (3) development, (4) comercialization, (5) deffusion and adoption, dan (6) conquences. Aspek manajemen yang menjadi urusan sekolah adalah ; (1) menetapkan visi, misi, strategi, tujuan, logo, lagu dan tata tertib sekolah, (2) memiliki kewenangan dalam penerimaan siswa baru (3) menetapkan kegiatan intrakurikuler dan ekstrakurikuler, (4) pengadaan sarana dan 
prasarana pendidikan, (5) perlengakapan barang dan jasa, (6) proses pengajaran dan pembelajaran, (7) urusan teknis edukatif lainnya.

Selain itu, manajemen pengetahuan selektif atau berbasis nilai pendekatan harus menjadi tiga-tier. Artinya, itu juga harus diterapkan tiga tingkat organisasi: individu, kelompok atau komunitas, dan organisasi itu sendiri. Cara terbaik untuk mempertahankan pengetahuan yang berharga adalah mengidentifikasi aset intelektual dan kemudian memastikan bahwa materi warisan diproduksi dan kemudian disimpan sedemikian rupa untuk membuat pengambilan dan penggunaan kembali di masa depan semudah mungkin. Produk sampingan yang nyata ini perlu mengalir dari individu ke individu, di antara anggota komunitas praktik, dan, tentu saja, kembali ke organisasi itu sendiri, dalam bentuk pembelajaran, praktik terbaik, dan memori perusahaan.

Berdasarkan pengumpulan data dari indikator yang telah didefinisikan, sekolah akan mendapatkan gambaran mengenai sejauh mana tingkat kapabilitas dan performansi dari Knowledge Management yang berjalan. Untuk melihat peningkatan ataupun penurunan performansi, maka pengukuran dengan indikator ini dapat dilakukan secara berkala. Indikator dari pengetahuan tentang manajemen dalam penelitian adalah (1) pengetahuan, (2) pemahaman, (3) penerapan, (4) analisis, (5) sintesis, dan (5) evaluasi

\section{Pendekatan Penelitian}

Pendekatan penelitian ini adalah penelitian kuantitatif. Menurut Sugiono, penelitian kuantitatif adalah penelitian yang berlandaskan pada filsafat positivisme, digunakan untuk meneliti pada populasi atau sampel tertentu, teknik pengambilan sampel pada umumnya dilakukan secara random, pengumpulan data menggunakan instrumen penelitian, analisis data bersifat kuantitatif/statistik dengan tujuan untuk menguji hipotesis yang telah ditetapkan. Menurut Creswell "Quantitative research is a type of educational research in which the researcher decides what to study, asks specific, narrow question, collect quantifiable data for participant, analyzes these numbers using statistics and conduct the inquiry in an unbiased, objective manner. Penelitian kuantitatif merupakan metode-metode untuk menguji teori-teori tertentu dengan cara meneliti hubungan antar variabel. Variabel-variabel ini diukur dengan menggunakan instrumen penelitian, sehingga data yang terdiri dari angka-angka dapat dianalisis berdasarkan prosedur-prosedur statistik.

Metode yang digunakan dalam penelitian ini adalah metode survei hubungan kausal, yang akan menguji pola hubungan dan pengaruh langsung dan tidak langsung, antara variabel eksogen (Pengetahuan Manajemen terhadap Kepuasan Kerja karyawan variabel endogen. Survey research designs are procedures in quantitative research in which investigation administer a survey to a sample or to the entire population of people to describe the atitudes, opinions, behaviors, or characteristics of population.

\section{KESIMPULAN DAN SARAN \\ Kesimpulan}

Berdasarkan analisis pengolahan data dan pembahasan yang telah dipaparkan pada bab sebelumnya. Maka diambil kesimpulan dalam penelitian ini antara lain: 
Pengetahuan manajemen berpengaruh positif dan signifikan terhadap kepuasan kerja karyawan secara simultan. Untuk meningkatkan kepuasan kerja karyawan melalui pengetahuan manajemen maka yang harus dilakukan oleh manajemen diantaranya adalah dengan memperhatikan perencanaan, pelaksanaan, pengorganisasian, pengawasan yang baik, pemimpinan harus mampu mempengaruhi orang lain dengan baik, dapat menggerakkan bawahan dengan baik, serta mampu untuk mengarahkan tingkah laku orang karyawannya dengan baik. Semakin baik pengetahuan manajemen yang dimiliki oleh karyawan yang dimiliki oleh seorang pemimpin, maka akan berdampak positif pula terhadap kepuasan kerja karyawan.

\section{Saran}

Berdasarkan kesimpulan dan implikasi diatas, dapat dikemukakan beberapa saran bagi perwujudan dan peningkatan kepuasan kerja karyawan di provinsi Kepulauan Riau sebagai berikut:

Pertama, hendaknya para kepala madrasah aliyah di provinsi Kepulauan Riau untuk memperbaiki pengetahuan manajemen, dalam melaksanakan tugas untuk peningkatan kepuasan kerja karyawan. Tiga hal ini secara sendiri-sendiri dan simultan memberikan pengaruh positif terhadap kepuasan kerja karyawan. Upaya peningkatan kepuasan kerja karyawan banyak dipengaruhi oleh pengetahuan manajemen. Hal ini menunjukkan bahwa pimpinan memiliki tanggungjawab bagi pengembangan kepuasan kerja karyawan.

Kedua, diharapkan kepala madrasah di provinsi Kepulauan Riau untuk mewujudkan kepuasan kerja karyawan untuk semua kegiatan di organisasi dan di luar organisasi madrasah di provinsi Kepulauan Riau berwenang dalam menumbuh kembangkan bagi seluruh karyawan. Dukungan pengelola sangat penting sebagai wujud nyata pelaksanaan tugas dan menjadikan organisasi sebagai agen perubahan yang mampu mendorong dan memotivasi terjadinya perubahan dalam semua aspek di madrasah. Pengelola madrasah dapat membantu karyawan dalam peningkatan kepuasan kerja karyawan melalui: (1) dengan meningkatkan pengetahuan manajemen, yang baik dicirikan oleh sifat-sifat yaitu (1) manusiawi; (2) memandang jauh kedepan; (3) inspiratif (kaya akan gagasan; dan (4) percaya diri.

\section{DAFTAR PUSTAKA}

Anonim. 2008. Al-Qur'an dan Terjemahnya. Jakarta: Departemen Agama RI.

Agus Irianto. 2012. Statistik Konsep Dasar, Aplikasi dan Perkembangannya. Jakarta: Kenacana Pranada Media Group.

Anwar Prabu Mangkunegara. 2009. Manajemen Sumber Daya Manusia Perusahaan. Bandung: Remaja Rosdakarya.

Arif Rahman. 2008. Prinsip-prinsip Sekolah Unggul, Jakarta: Media Wacana.

Arief S Sadiman. 2009. Media Pendidikan, Jakarta: PT Raja Grafindo Persada.

Bambang Prasetyo dan lina Miftahul Jannah. 2012. Metode Penelitian Kuantitatif. Jakarta: Raja Grafindo Persada.

Briner Rob B. and Walshe Neil D.,Psychologyof Leadership, Change, and Organizational Development. 2013. West Sussex: John Wiley \& Sans,Ltd. 
Bush Tony. 2008. Leadership and Management Development In Education. London: SAGE Publications Ltd.

Champoux Joseph E. 2011. Organizational Behavior: integrating individual, Groups, and Organizations. New York : Routledge.

Colquitt Jason A., LePine Jeffery A., and Wesson Michael J. 2009. Oganizational Behavior Improving Performance and Commitment in the Workplace. New York. McGraw-Hill.

Creswell John W. 2015. Educational Research Planning, Conducting, and Evaluating Quantitative and Qualitative Research, Fifth Edition, (New Jersey: Pearson Educational, Inc.

Edy Sutrisno. 2012. Manajemen Sumber Daya Manusia. Jakarta: Kencana Prenada Media Group.

E. Mulyasa. 2009. Menjadi Guru Profesional, Bandung, Remaja Rosdakarya.

George Jennifer M, and Jones Gareth R. 2012. Understanding and Managing Organizational Behavior, Sixth Editon. New Jersey: Pearson Edukational Inc.

George Jennifer m., and Jones Gareth R. 2008. Understanding and Managing Organizational Behavior, Fifth Edition. New Jersey: Pearson Education, Inc.

George R Terry. 2009. Principles of Management, terj. Winardi, Alumni.

HE. Mulyasa. 2013. Manajemen \& Kepemimpinan Kepala Sekolah. Jakarta: PT Bumi Aksara.

Hery Noer Aly dan Muzier. 2008. Watak Pendidikan Islam, Bandung: CV. Pustaka Setia.

Hikmat. 2009. Manajemen Pendidikan, Bandung: Pustaka Setia.

Husaini Usman. 2014. Manajemen Teori, Praktik, dan Riset pendidikan, Edisi keempat. Jakarta: Bumi Aksara.

Husaini Usman. 2014. Manajemen Teori, Praktik, dan Riset Pendidikan, Edisi keempat. Jakarta: Bumi Aksara.

Hussein Fattah. 2014. Perilaku Pemimpin \& Kinerja Pegawai, Budaya Organisasi, Efikasi Diri, dan Kepuasan Kerja. Yogyakarta: Elmatera.

Iskandar. 2014. Metodologi Penelitian Pendidikan dan Sosial Kuantitatif dan Kualitatif. Jakarta: Gaung Persada Press.

Judge Timothy A. And Klinger Ryan. 2009. Handbook Of Principles Of Organizational Behavior, Second Edition. United Kingdom: John Wiley \& Sons, Ltd.

Kadir. 2015. Satatistika Terapan Konsep, Contoh dan Analisis Data Dengan Program SPSS/Lisrel Dalam Penelitian. Jakarta: PT Raja Grafindo Persada.

Lexy J. Moleong. 2010. Metodologi Penelitian Kualitatif, Bandung : PT. Remaja Rosda Karya.

Luthans Fred. 2011. Organizational Behaviore An Evidence-Based Approach, Edisi ke-dua belas. New York, McGraw-hill/Irwin.

M. Zainuddin. 2008. Paradigma Pendidikan Terpadu Menyiapkan Generasi Ulul Albab, Malang: UIN Malang Press.

Mansur. 2011. Diskurnas Pendidikan Islam, Yogyakarta: Global Pustaka Utama.

Mulyono Abdurrahman. 2009. Pendiddikan Bagi Anak Berkesulitan Belajar. Jakarta: Pusat Perbukuan Departemen Pendidikan Dan Kebudayaan. 
Muhibbin Syah. 2009. Psikologi Belajar, Jakarta: PT Raja Grafindo Persada.

Mukhtar. 2013. Metode Praktis Penelitian Deskriftif Kualitatif, Jakarta : GP Press Group.

Norman K. Denzin \& Yvonna S. Lincoln. 2008. Handbook Of Qualitative Research, California:Teller, Road Thousand Oaks.

Nana Syaodih Sukmadinata. 2011. Metode Penelitian Pendidikan, Bandung : PT. Remaja Rosda Karya.

Mc Crae Robert R., and Costa Paul T. 2009. Personality in Adulthood A Five-Factor Theory Perspective, Second Edition. New York, The Guilford Press.

Merry Michael s. 2009. Culture, Identity, and Islamic Schooling A Philosophical Approach. New York : Palgrave Macmillan.

Northouse Peter G. 2013. Kepemimpinan Teori dan Praktik, Alih Bahasa: Ati Cahayani, Edisi Keenam. Jakarta: PT Indeks.

Punaji Setyosari. 2013. Metode Penelitian Pendidikan \& Pengembangan, ( Jakarta: Kencana Prenadamedia Group.

Purwa Atmaja Prawira. 2013. Psikologi Kepribadian dengan Persektif Baru. Yogyakarta: Ar-ruzz Media.

Purwanto, N. 2010. Psikologi Pendidikan. Bandung, Remaja Rosdakarya.

Ramayulis dan Samsul Nizar. 2009. Ensiklopedi Tokoh Pendidikan Islam. Jakarta: PT. Ciputat Press Group.

Reni Harwadi 2009. Akselerasi, Jakarta: PT Gramedia Widiasarana Indonesia.

Rostina Sundayana. 2014. Statistika Penelitian Pendidikan. Bandung: Alfabeta.

Sudarwan Danim. 2008. Kinerja Staf dan Organisasi. Bandung: CV Pustaka Setia.

Suharsimi Arikunto. 2010. Prosedur Penelitian Suatu Pendekatan Praktik, Jakarta: Rineka Cipta.

Sugiyono. 2008. Memahami Penelitian Kualitatif, Bandung: Alfabeta.

Supardi U. S. 2014. Aplikasi Statistika Dalam Penelitian Konsep Statistika yang Lebih Komprehensif. Jakarta: Change Publication.

Syamsul Kurniawan dan Erwin Mahrus. 2011. Jejak Pemikiran Tokoh Pendidikan Islam, Yogjakarta: Ar-Ruzz Media.

Trianto. 2010. Pengantar Penelitian Pendidikan Bagi Pengembangan Profesi pendidikan \& Tenaga kependidikan. Jakarta: Kencana Prenada Media Group.

Veithzal Rivai Zainal, dkk. 2013. Islamic Management Meraih Sukses Melalui Praktik Manajemen Gaya Rasulullah Secara istiqomah. Yogyakarta: BPFE.

Wibowo. 2013. Perilaku Dalam Organisasi. Jakarta: PT Raja Garafindo Persada.

Wibowo. 2011. Manajemen Kinerja, Jakarta: Rajawali Pers.

Yukl, Gary. 2015. Kepemimpinan dalam Organisasi, Edisi ketujuh, Alih Bahasa Ati Cahayani. Jakarta: PT Indeks. 